\title{
Şinasi Özsoylu
}

\section{Megadose methylprednisolone for Kasabach-Merritt syndrome}

Received: 16 July 2002 / Accepted: 21 November 2002/Published online: 14 May 2003

(C) Springer-Verlag 2003

Frevel et al. [2], in their review article on KasabachMerritt syndrome (KMS), failed to mention megadose methylprednisolone (MDMP) treatment for this condition as was first published by us [8] in this journal in 1989. By stating: "Corticosteroids given at a dose of 2 to $3 \mathrm{mg} / \mathrm{kg}$ body weight per day are treatment of choice" for the treatment of haemangiomas, the authors seem to ignore the comparative study by Uysal et al. [9] who showed clearly that oral MDMP is better than $2 \mathrm{mg} / \mathrm{kg} /$ day of corticosteroids.

Although the authors stated: "KMS resistant to corticosteroid can be treated with INF", evidence indicates that resistance could be better overcome by use of MDMP in different conditions [1, 4, 5, 6, 7]. Another statement, "Rare side-effects of long-term treatment with high doses above $5 \mathrm{mg} / \mathrm{kg}$ body weight daily include the risk of growth suppression, osteoporosis and opportunistic infections", was made by the authors without reference. But, none of these side effects were observed by Bernini et al. [1], which supported our previous findings $[5,7,8]$.

The authors also failed to mention the earlier study of Inceman and Tangün, which was the first direct evidence of local consumption of platelets and intralesional coagulation abnormalities [3].

I was surprised to read details of the very expensive interferon treatment for KMS without mentioning the results of the use of MDMP for this condition.

\section{References}

1. Bernini JC, Carillo M, Buchanon GR (1995) High dose intravenous methylprednisolone therapy for patients with DiamondBlackfan anemia refractory to conventional doses of prednisone. J Pediatr 127:654-659

2. Frevel T, Rabe H, Ückert F, Harms E (2002) Giant cavernous haemangioma with Kasabach-Merritt syndrome: a case report and review. Eur J Pediatr 161:243-246

3. Inceman S, Tangün Y (1969) Chronic defibrination syndrome due to a giant hemangioma associated with microangiopathic hemolytic anemia. Am J Med 46:997-1002

4. Özsoylu S (1984) High dose intravenous corticosteroid for a patient with Diamond-Blackfan syndrome refractory to classical prednisone treatment. Acta Haematol 71:207-210

5. Özsoylu Ş (1988) High dose intravenous corticosteroid treatment for patients with Diamond-Blackfan syndrome resistant or refractor to conventional treatment. Am J Pediatr Hematol Oncol 10:210-217

6. Özsoylu Ş (1990) High dose intravenous methylprednisolone for pure red cell aplasia [letter]. Am J Hematol 34:236

7. Özsoylu Ş (1990) High dose intravenous methylprednisolone (HIVMP) in haematologic disorders. Hematol Rev 4:197-207

8. Özsoylu Ş, İrken G, Gürgey A (1989) High dose intravenous methylprednisolone for Kasabach-Merritt syndrome. Eur J Pediatr 148:403-495

9. Uysal KM, Olgun N, Erbay A, Sarıalioğlu F (2002) High dose oral methylprednisolone therapy in childhood hemangiomas. Pediatr Hematol Oncol 18:335-341

\footnotetext{
Ş. Özsoylu

Medical Faculty, Fatih University,

Alparslan Türkes cad. No.57, 06510, Emek-Ankara, Turkey

E-mail: sinasi.ozsoylu@fatihmed.edu.tr

Fax: + 90-312-2213276
} 